\title{
Pelatihan Penyusunan Modul Blended Learning Sebagai Upaya Pembelajaran Kreatif Abad 21
}

\author{
R. Eka Murtinugraha ${ }^{1}$, Ririt Aprilin S2, M. Agphin Ramadhan*3 \\ 1,2,3 Program Studi Pendidikan Teknik Bangunan Universitas Negeri Jakarta \\ *e-mail: r_ekomn@unj.ac.id¹ ${ }^{1}$,ririt-aprilin@unj.ac.id ${ }^{2}$, agphin@unj.ac.id*3
}

\begin{abstract}
The 21st century is a digital age. Communication is carried out across national borders using increasingly sophisticated technological devices. Various industries and manufacturers felt these technological advances. However, of the various fields that exist, education is the field that feels the most positive impact on advances in technology and information. One of the applications of 21st-century learning is the blended learning module. Blended learning-based modules will provide new colors that can be easily carried out by students with teacher guidance. One of the advantages of the blended learning module is that the teaching materials provide experience for students in independent learning by carrying out instructions for doing assignments by accessing materials online. This activity aims to train participants in compiling Blended Learning modules in learning. The participants were 45 teachers of SMKN 6 Kota Bekasi and SMKN 1 Cikarang Barat. The increase in pretest (62.22) to post-test (69.33) shows that the participants' understanding of the Blended Learning module's preparation has increased.
\end{abstract}

Keywords: Module, Blended Learning, 21 ${ }^{\text {st }}$ Century

\begin{abstract}
Abstrak
Abad ke-21 adalah abad digital. Komunikasi dilakukan melewati batas wilayah negara dengan menggunakan perangkat teknologi yang semakin canggih. Kemajuan teknologi tersebut dirasakan oleh berbagai industri dan manufaktur. Namun dari berbagai bidang yang ada, pendidikan adalah bidang yang paling merasakan dampak positif terhadap kemajuan teknologi dan informasi. Salah satu penerapan pembelajaran abad 21 adalah modul blended learning. Modul berbasis blended learning akan memberikan warna baru yang dapat dengan mudah dilakukan oleh siswa dengan bimbingan guru. Salah satu kelebihan modul blended learning yaitu bahan ajarnya memberikan pengalaman bagi peserta didik dalam belajar mandiri dengan melakukan intruksi-instruksi untuk melakukan tugas dengan bisa mengakses materi-materi secara online. Kegiatan ini bertujuan untuk melatih peserta dalam menyusun modul Blended Learning yang dapat digunakan pada pembelajaran. Peserta merupakan guru-guru SMKN 6 Kota Bekasi dan SMKN 1 Cikarang Barat sejumlah 45 orang. Peningkatan nilai dari pretest $(62,22)$ ke posttest $(69,33)$ menunjukkan pemahaman peserta mengenai penyusunan modul Blended Learning meningkat.
\end{abstract}

Kata kunci: Modul, Blended Learning, Abad 21

\section{PENDAHULUAN}

Abad ke-21 adalah abad digital. Komunikasi dilakukan melewati batas wilayah negara dengan menggunakan perangkat teknologi yang semakin canggih (Iriani dan Ramadhan, 2019). Kemajuan teknologi tersebut dirasakan oleh berbagai industri dan manufaktur dengan teknologi dan informasi dapat mempermudah dalam aktifitas manusia (Yandra:2018). Namun dari berbagai bidang yang ada, pendidikan adalah bidang yang paling merasakan dampak positif terhadap kemajuan teknologi dan informasi. Hal ini dinyatakan oleh (Fardhany 2016) bahwa pemanfaatan teknologi komunikasi dan informasi dalam proses pembelajaran memiliki dampak positif terhadap peforma dan prestasi pada peserta didik. Menurut Prayitno (2015), dunia pendidikan termasuk yang paling diuntungkan dari kemajuan Teknologi Informasi dan Komunikasi karena memperoleh manfaat yang luar biasa. Dari eksplorasi sumber belajar berkualitas seperti literatur, jurnal, dan buku, membangun forum-forum diskusi 
ilmiah, sampai konsultasi/diskusi dengan para pakar atau ahli di dunia. Karakteristik seperti inilah yang menjadi ciri dari pembelajaran abad 21. Lim et al. (2020) menyatakan kemampuan bagi siswa untuk mengatur pembelajaran mereka sendiri dan belajar efektif dengan teman sebaya menjadi dua kompetensi khas di era keempat Revolusi Industri.

Salah satu penerapan pembelajaran abad 21 adalah modul blended learning. Airlanda (2016) menyatakan modul berbasis blended learning akan memberikan warna baru yang dapat dengan mudah dilakukan oleh siswa dengan bimbingan guru. Peneliti mengembangkan modul berbasis home science process skill akan dipadukan dengan pendekatan blended learning. Matondang (2018) mengatakan bahwa menggunakan modul berbasis blended learning untuk siswa yang sedang melaksanakan prakerin adalah salah satu solusi untuk tetap melaksanakan pembelajaran selama melaksanakan kegiatan prakerin. Fahrurrozi \& Majid (2017) mengembangkan modul praktis dengan model blended learning berbasis Edmodo. Media tersebut layak digunakan sebagai pedoman pelaksanaan pembelajaran di kelas. Kelebihan lain dijelaskan oleh Suhartini et al. (2019) salah satu kelebihan modul blended learning yaitu bahan ajarnya memberikan pengalaman bagi peserta didik dalam belajar mandiri dengan melakukan intruksi-instruksi untuk melakukan tugas dengan bisa mengakses materi-materi secara online. Priono et al. (2019) membuktikan pengaruh penerapan model pembelajaran blended learning dapat meningkatkan hasil belajar siswa pada materi menggambar 2 dimensi menggunakan CAD. Selain itu dengan adanya media pembelajaran akan meningkatkan proses komunikasi antara pembelajar dengan pengajar (Desyanti, Muztazihim Suhaidi 2019)

Dalam pengembangannya merancang modul online harus memperhatikan program studi dan materi pelajaran karakteristik, jenis kuliah (kuliah teoretis atau praktis), fitur sistem manajemen pembelajaran, fasilitas pendukung, peran guru dalam mempersiapkan dan memfasilitasi kursus, kegiatan siswa dan persepsi mereka (Cahyono et al. 2019). Andersson \& Logofatu (2017) mengembangkan modul berbasis blended learning dengan dua bagian, yaitu bagian teoritis dan bagian praktis. Gambar di bawah ini menjelaskan langkah-langkah yang dimaksud.

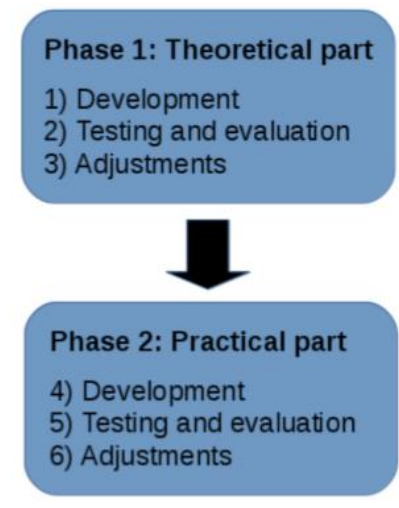

\section{Gambar 1. Enam Langkah dalam Dua Fase Pengembangan}

Sumber: Andersson \& Logofatu, 2017

Hal yang membedakan modul blended learning dengan modul lainnya dijelaskan oleh Hill et al. (2017) yang menyatakan bahwa modul online (blended learning) dirancang sebagai latihan untuk diselesaikan siswa agar siap belajar di pertemuan berikutnya. Modul setiap pertemuan dibagi menjadi tiga bagian singkat: 1) Informasi, 
dimana konten disajikan; 2) Pertanyaan, dimana siswa ditanyai pertanyaan terkait konten; 3) Refleksi, dimana siswa diminta menggunakan pertanyaan metakognitif untuk bercermin pembelajaran mereka. Ketiga bagian tersebut terintegrasi dengan teknologi learning management system. Engel et al. (2019) menyatakan bahwa di masa depan implementasi modul blended learning akan berkembang ke tingkat yang lebih tinggi.

Sebagai analisis situasi kegiatan pengabdian masyarakat di Sekolah Mitra diketahui bahwa sekolah tersebut belum mengaplikasikan blended learning. Pembelajaran yang dilakukan selama ini menggunakan pembelajaran konvensional. Terdapat 6 orang guru yang mengajar di sana. Berdasarkan wawancara, guru-guru tersebut belum mengetahui blended learning dan belum pernah membuat modul. Oleh karena itu, kegiatan pengabdian masyarakat ini bertujuan untuk memberikan pelatihan pembuatan modul blended learning.

\section{METODE}

Pelatihan ini dilaksanakan pada 12 September 2020 dalam bentuk webinar dengan bantuan aplikasi Zoom Meeting dikarenakan sedang berada pada masa pandemi Covid19. Target luaran kegiatan ini adalah untuk memberikan gambaran umum dan menambah keterampilan guru-guru di Sekolah Mitra dalam membuat modul blended learning. Metode yang digunakan adalah ceramah dan tutorial. Kegiatan ini dibagi dalam 2 (dua) tahap, yakni: (1) penjelasan teori, berisi teori dan konsep blended learning; (2) tutorial penyusunan modul blended learning. Kemudian evaluasi dilakukan dengan dua tahap, yakni evaluasi penguasaan teori dan evaluasi keterampilan praktik lapangan.
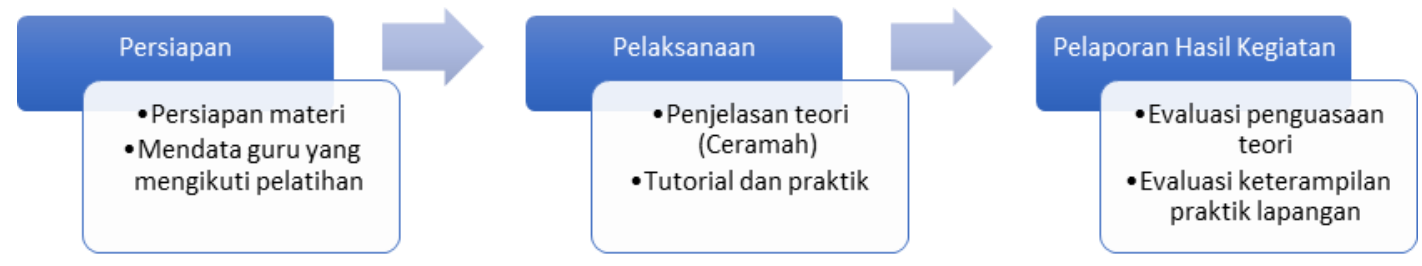

Gambar 2. Alur Tahapan Pelaksanaan Kegiatan

\section{HASIL DAN PEMBAHASAN}

Kegiatan pelatihan dilaksanakan dalam bentuk webinar melalui aplikasi Zoom. Peserta yang mengikuti kegiatan ini sebanyak 45 peserta yang merupakan guru SMK dari SMKN 6 Kota Bekasi dan SMKN 1 Cikarang Barat. Selain itu, terdapat pula guruguru dari beberapa sekolah di Cileungsi Bogor, Tangerang, Depok, Cirebon, Garut, Bandung, Ciamis, Kuningan, Bali, Makassar hingga Kabupaten Donggala, Sulawesi Tengah yang mengikuti kegiatan ini.

Kegiatan pelatihan diawali dengan memberikan pre-test kepada peserta untuk dikerjakan terlebih dahulu. Kemudian, narasumber memaparkan materi berupa teori dan konsep blended learning serta tutorial penyusunan modul blended learning. Setelah pemaparan materi, peserta diberikan waktu untuk sesi tanya jawab terkait materi yang disampaikan. Jika sesi tanya jawab selesai, peserta diberikan post-test untuk mengetahui apakah pelatihan ini dapat menambah wawasan dan keterampilan peserta 
dalam menyusun modul blended learning. Selanjutnya, peserta diberikan angket evaluasi mengenai kegiatan pelatihan ini.

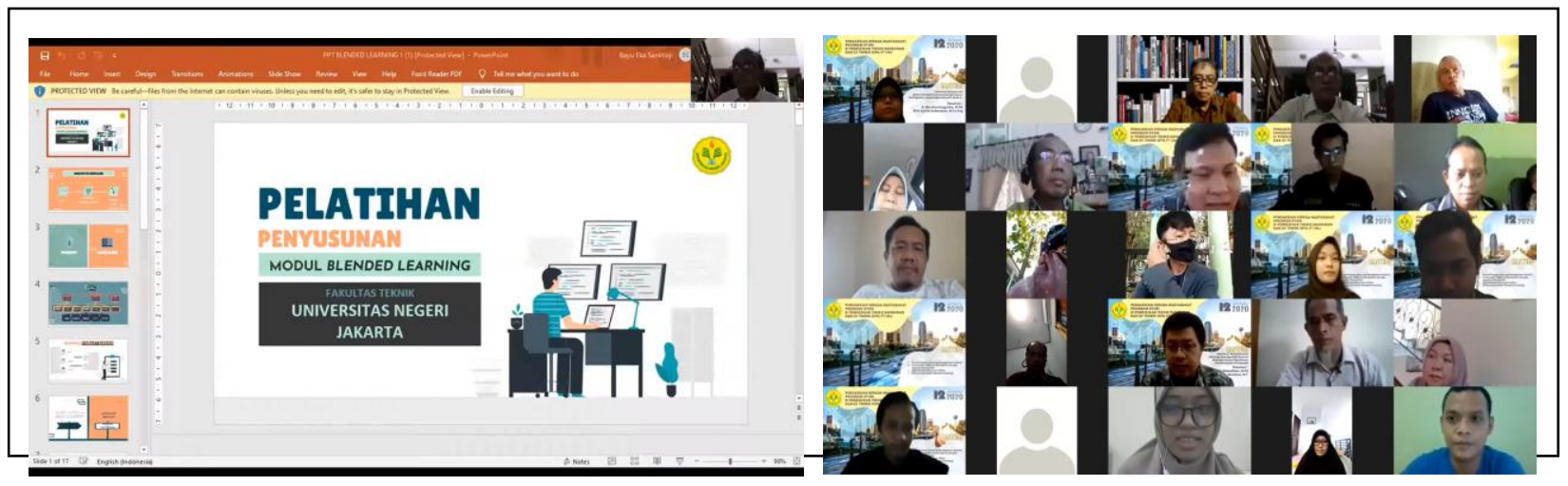

\section{Gambar 3. Pelaksanaan Pelatihan Penyusunan Modul Blended Learning}

Peserta kegiatan pelatihan diberikan modul pelatihan penyusunan modul blended learning yang berisi tentang materi, konsep, serta tutorial cara pembuatan modul, sehingga peserta dapat lebih mendalami materi dan dapat mencoba membuat modul setelah mengikuti kegiatan pelatihan.

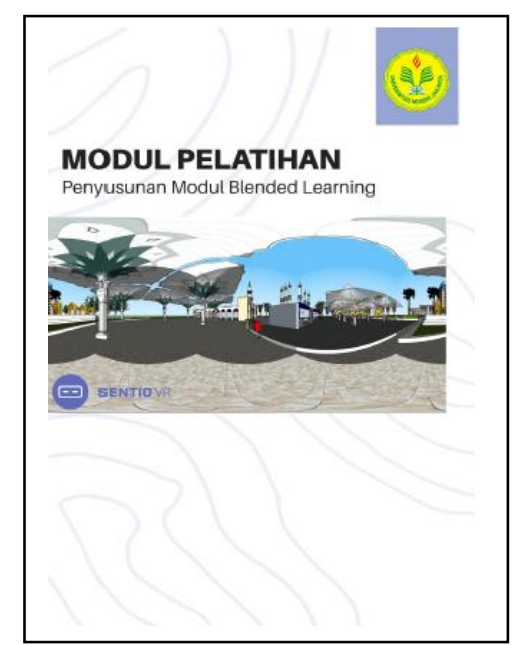

\section{Gambar 4. Modul Pelatihan Penyusunan Modul Blended Learning}

Hasil rata-rata nilai pre-test yang diperoleh peserta sebesar 62,22. Setelah diberikan materi mengenai penyusunan modul blended learning, rata-rata nilai posttest meningkat sebesar 69,33. Hasil pre-test dan post-test yang diperoleh dapat dilihat pada grafik berikut.

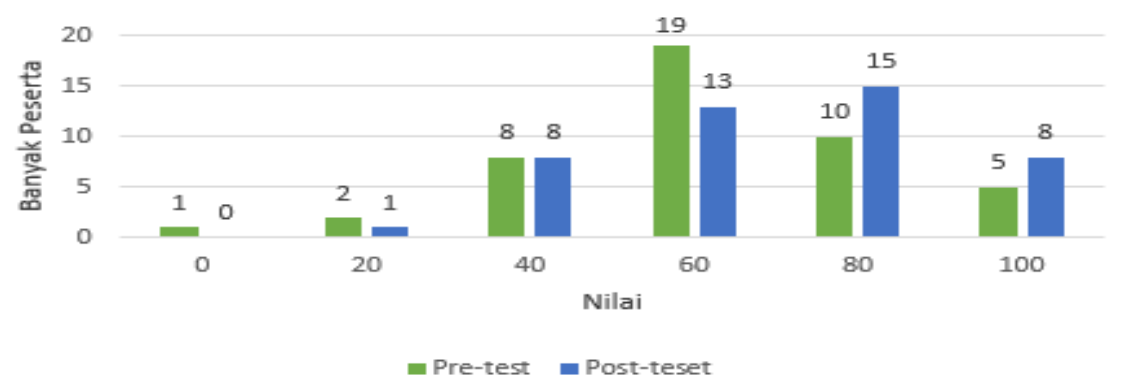

Gambar 5. Grafik Hasil Pre-test dan Post-test 
Pada gambar 5 menunjukan bahwa terjadi penurunan banyaknya peserta yang memperoleh nilai 0, 20, 40 dan peningkatan banyaknya peserta yang memperoleh nilai 80 dan 100. Oleh karena itu dapat dikatakan bahwa terjadi peningkatan nilai yang diperoleh peserta setelah diberikan materi oleh narasumber.

Adapun hasil angket evaluasi kegiatan yang diisi oleh peserta mendapatkan hasil sebagai berikut:

1. Peserta kegiatan menilai penyampaian materi oleh narasumber dengan kategori sangat baik sebesar $67 \%$ dan kategori baik sebesar 33\%. Berdasarkan persentase tersebut dapat dikatakan bahwa sebagian besar peserta menilai penyampaian materi yang dilakukan oleh narasumber sangat baik. Hasil penyampaian materi oleh narasumber dapat dilihat pada grafik di bawah ini.

\section{PENYAMPAIAN MATERI OLEH NARASUMBER}

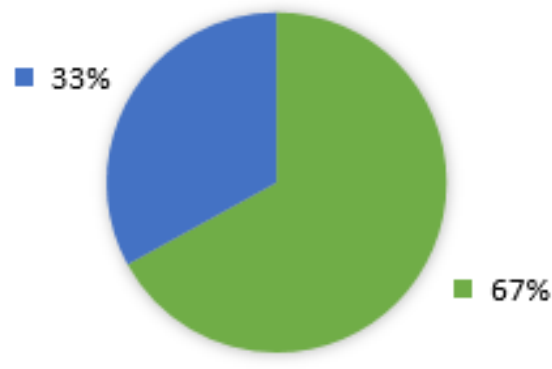

$$
\begin{aligned}
& \text { - Sangat Baik } \\
& \text { - Baik } \\
& \text { = Cukup Baik } \\
& \text { - Tidak Baik } \\
& \text { - Sangat Tidak Baik }
\end{aligned}
$$

\section{Gambar 6. Diagram Evaluasi Penyampaian Materi Oleh Narasumber}

2. Peserta menilai seluruh rangkaian kegiatan dilaksanakan dengan kategori sangat baik sebesar $69 \%$, kategori baik sebesar $27 \%$, dan kategori cukup baik sebesar $4 \%$. Berdasarkan persentase tersebut, dapat disimpulkan bahwa sebagian besar peserta menilai rangkaian kegiatan pelatihan ini dilaksanakan dengan sangat baik.

\section{KESELURUHAN RANGKAIAN}

KEGIATAN

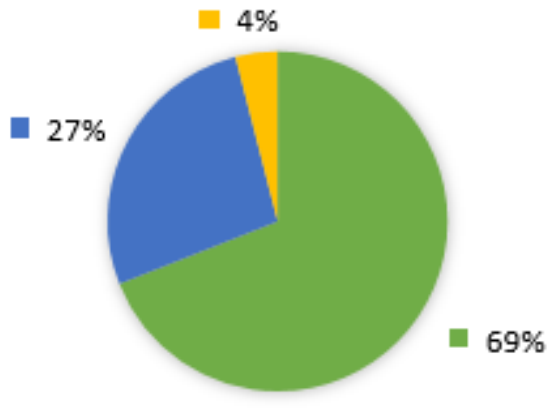

$$
\begin{aligned}
& \text { - Sangat Baik } \\
& \text { - Baik } \\
& \text { n Cukup Baik } \\
& \text { - Tidak Baik } \\
& \text { - Sangat Tidak Baik }
\end{aligned}
$$

Gambar 7. Diagram Evaluasi Rangkaian Kegiatan 
3. Sebagian peserta yang sangat setuju ingin mencoba membuat modul blended learning sebesar 53\%, peserta yang setuju sebesar $40 \%$, peserta yang cukup setuju sebesar $5 \%$, dan peserta yang sangat kurang setuju sebesar $2 \%$. Berdasarkan hasil tersebut, dapat disimpulkan bahwa sebagian peserta tertarik dalam membuat modul blended learning. Hasil persentase tersebut dapat dilihat pada grafik berikut.

\title{
MENCOBA MEMBUAT MODUL BLENDED LEARNING
}

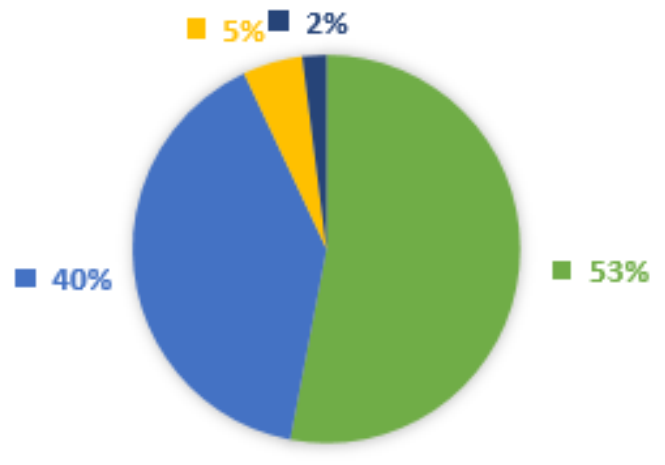

\author{
- Sangat Setuju \\ - Setuju \\ - Cukup Setuju \\ - Tidak Setuju \\ - Sangat Tidak Setuju
}

\section{Gambar 8. Diagram Evaluasi Mencoba Modul Blended Learning}

Pada angket evaluasi kegiatan, peserta juga memberikan saran terkait kegiatan pelatihan penyusunan modul blended learning ini, yaitu: (1) Dapat diadakan kembali guna menambah wawasan dan keterampilan; (2) Jam atau hari pelatihan ditambahkan karena terlalu singkat; (3) Semoga dapat dilakukan pelatihan secara offline ketika pandemi berakhir; (4) Penyampaian narasumber terlalu cepat dikarenakan batas waktu.

\section{KESIMPULAN}

Kegiatan pelatihan penyusunan modul blended learning telah dilaksanakan melalui webinar yang diikuti oleh guru-guru baik dari Sekolah Mitra maupun luar Sekolah Mitra. Berdasarkan kegiatan ini dapat disimpulkan sebagai berikut: 1) Hasil perolehan pre-test dan post-test mengalami peningkatan nilai rata-rata peserta setelah diberikan materi oleh narasumber; 2) Para peserta merespon kegiatan pelatihan ini dengan respon yang positif berdasarkan angket evaluasi kegiatan; dan 3) Berdasarkan angket evaluasi kegiatan, para peserta tertarik untuk mencoba membuat modul blended learning. Kegiatan pelatihan ini dilakukan untuk memberikan gambaran umum dan menambah keterampilan guru-guru di Sekolah Mitra dalam membuat modul blended learning. Kesibukan mengajar dan kegiatan akademik lainnya biasanya membuat guru-guru kesulitan untuk menambah wawasan dan pengetahuan mereka, khususnya mengenai teknologi dan informasi terkini. Oleh karena itu, kegiatan pengabdian masyarakat hadir untuk memberikan pelatihan bagi para guru. Kegiatan ini sangat bermanfaat karena menambah keterampilan, pengetahuan dan pengalaman. Walaupun kegiatan ini dilakukan secara daring dan singkat dikarenakan pandemi, tetapi diharapkan dapat memberikan manfaat dalam meningkatkan pembelajaran yang juga dilakukan secara daring pada saat ini. 


\section{UCAPAN TERIMA KASIH}

Tim penulis mengucapkan terima kasih kepada Dekanat Fakultas Teknik Universitas Negeri Jakarta yang telah mendukung kegiatan ini secara finansial. Tim penulis juga sampaikan kepada guru-guru SMKN 6 Kota Bekasi dan SMKN 1 Cikarang Barat, serta guru-guru dari seluruh wilayah Indonesia yang telah mengikuti kegiatan ini.

\section{DAFTAR PUSTAKA}

Airlanda, G., 2016. engembangan modul pembelajaran biologi berbasis hsps dipadukan blended learning untuk meningkatkan keterampilan proses sains siswa XI IPA SMA Kristen Petra Malang. Jurnal Pendidikan Sains (Jps), 4(1), pp.1-5.

Andersson, C. \& Logofatu, D., 2017. A Blended Learning Module in Statistics for Computer Science and Engineering Students Revisited Current Situation at FRAUAS for Teaching Statistics. $i$-JEP, 7(4), pp.66-77.

Cahyono, A.N., Zaenuri \& Subagja, M., 2019. The Design of Blended Learning Modules for Higher Education. Journal of Physics: Conference Series, 1387(1).

Desyanti, Muztazihim Suhaidi, F., 2019. Meningkatkan kemampuan menghafal juz amma melalui media pembelajaran audio visual. Seminar Nasional Pemberdayaan Masyarakat, 1(Unri Conference Series: Community Engagement. Volume 1 ISSN 2685-9017), pp.297-303.

Engel, B., Esser, M. \& Bleckwenn, M., 2019. Piloting a blended-learning concept for integrating evidence-based medicine into the general practice clerkship. GMS Journal for Medical Education, 36(6), pp.1-14.

Fahrurrozi, M. \& Majid, M.A., 2017. Pengembanggan Model Pembelajaran Blended Learning Berbasis Edmodo dalam Membentuk Kemandirian Belajar Siswa Pada Mata Pelajaran Ekonomi Kelas Xi Ips Sman 1 Selong Tahun Pelajaran 2017/2018. JPEK (Jurnal Pendidikan Ekonomi dan Kewirausahaan), 1(1), p.57.

Fardhany, P.H., 2016. Pemanfaatan Bahan Ajar Berbasis Blended Learning Dalam Pendidikan Jasmani Olahraga Dan Kesehatan. , pp.456-471.

Hill, M., Sharma, M. \& Xu, Y., 2017. Pre-lecture online learning modules in university physics: Student participation, perceptions and performance. International Journal of Innovation in Science and Mathematics Education, 25(1), pp.14-32.

Lim, C.L. et al., 2020. Peer Learning , Self-Regulated Learning and Academic Achievement in Blended Learning Courses : A Structural Equation Modeling Approach. International Journal of Emerging Technologies in Learning, 15(3), pp.110-125.

Matondang, P.-, 2018. Blended Learning Pengembangan Modul Pembelajaran Berbasis Blended Learning Mata Pelajaran Rancang Bangun Jaringan. Pedagogi: Jurnal Ilmu Pendidikan, 17(2), p.13.

Prayitno, W., 2015. Implementasi Blended Learning dalam Pembelajaran pada Pendidikan Dasar dan Menengah. Artikel LPMP D.I. Yogyakarta, pp.1-14.

Priono, A.I., Purnawan, P. \& Komaro, M., 2019. Pengaruh Penerapan Model Pembelajaran Blended Learning Terhadap Hasil Belajar Menggambar 2 Dimensi Menggunakan Computer Aided Design. Journal of Mechanical Engineering Education, 5(2), p.129.

Suhartini, N., Sumbawati, M.S. \& Sitompul, N.C., 2019. Pengembangan Modul Pembelajaran IPS Berorientasi Student Center Learning dalam Blended Learning Kelas VII di SMP Negeri 4 Surabaya. Education and Development, 7(3), pp.304311. 
ABDINE: Jurnal Pengabdian Kepada Masyarakat Vol. 1, No.2, Desember 2021,Hal. 79-86 p-ISSN 2798-2882, e-ISSN 2798-2890

Tuti Iriani dan M. Agphin Ramadhan, 2019. Pelatihan manajemen bank sampah bagi masyarakat di kecamatan muara gembong. Jurnal Pengabdian Kepada Masyarakat, 1(1), pp.1-10.

Yandra, A., \& Febriadi, B. (2018). PELATIHAN PENGGUNAAN APLIKASI PENDETEKSI PALGIAT UNTUK DOSEN UNIVERSITAS LANCANG KUNING. Dinamisia: Jurnal Pengabdian Kepada Masyarakat, 2(2), 283-286. 